\title{
Aromatization of Hantzsch 1,4-Dihydropyridines with [Hydroxy(tosyloxy)iodo]benzene
}

\author{
Kang-Hyeok Lee and Kwang-Youn Ko ${ }^{\star}$ \\ Department of Chemisty. Ajou Universily, Sinwon $4+2-749$, Korea \\ Received Jume 28, 2002
}

Key Words : 1,4-Dihydropyridines, Aromatization, ]lypervalent iodine

I Jantzsch 1,4-dihydropyridines (1, I Jantzsch 1,4-DIJPs) are widely used as calcium channel blockers for the treatment of cardiovascular disorder including angina, hypertension and cardiac arrhythmias.' These compounds are oxidized to pyridine derivatives by the action of cytochrome P-450 in the liver: ${ }^{2}$ In this respect, a convenient preparation of pyridines from 1,4-DH IPs is important for the identification of metabolites. Furthermore, the oxidation of I Iantzsch1,4-DH IPsprovidesaneasyacesstopyridinoderivatives. Oxidation of 1,4-DH IPs has been achicved using various oxidants. ${ }^{i}$ l lowever, some methods sufler from low ehemical yields, ${ }^{i-1-k}$ strong oxidative conditions, ${ }^{3,-b . t}$ cumbersome workup ${ }^{3-k}$ side-product formation ${ }^{3.1}$ or long reaclion time. ${ }^{3 j}$ We reported that I Iantzsch I,4-DIJPs can be aromatized to pyridines by Magtrieve ${ }^{\mathrm{j} y}$, a magnetically retricvable and environmentally safe oxidant $\left(\mathrm{CrO}_{2}\right){ }^{4}$ ln continuing our eflorts to find a milder and high-yiclding oxidant for the I Iantzsch I,4-D] JPS, herein we wish to report that [hydroxy(1osyloxy)iodo]benzene (JTIB, PhI(OH l)OTs, Koser"s reagent) can serve as a powerlul oxidant for the aromatization of the I Jantzsch 1.4-DH IPs.

Ilypervalent iodine(ll]) and iodine(V) reagents have been uscd as green-oxidants for a variety of substrates. ${ }^{6}$ Literature survey showed that phenyliodine(II]) bis(trilluoroacetate) $\left(\mathrm{Phl}(\mathrm{OCOCF})_{2}, \mathrm{PIFA}\right)$ was already used for the solid state oxidation of 1,4-DH IPs under microwave irradiation conditions. ${ }^{i}$ One drawback of this reagent is that dealkylation occurs even in the case of 4-cthyl-1,4-DIJP. When we atlempted the oxidation of 1 a ( $\mathrm{R}$ - phenyl) with iodobenzene diacelate (PhI $(\mathrm{OAc})_{2}$ ), a non-fluorinated analog of PJFA in $\mathrm{CH}_{2} \mathrm{Cl}_{2}$ at room temperature, the oxidation was not completed within $5 \mathrm{~h}$, giving a $3: 1$ mixture of 2 a and $\mathbf{1 a}$. Further search for the eflicient hypervalent iodine oxidants led to the finding that IJTIB $^{8}$ is an extremely eflicient reagent for the aromatization of 1,4-DH IPs, as shown in Scheme 1.

As shown in Table I, the oxidation of 1,4-DIJs with IITIB was completed within just a few minutes in $\mathrm{CI}_{2} \mathrm{Cl}_{2}$ at room temperature, requiring no activation such as microwave irradiation ${ }^{7}$ or ultrasound. ${ }^{3 e}$ HTTIB was found to be equally effective for the aromatization of 1.4-DIJPs bearing an alkyl group or an aryl group in the 4-position. ${ }^{3 .} \mathrm{Nlso}$, dealkylation of 4-cthyl derivative $1 \mathbf{j}$. which was observed during PIFA oxidation ${ }^{7}$ did not oceur in the present case. Ilowever, as observed in the oxidation with C.r(VI) ${ }^{3 \mathrm{i}-\mathrm{d}}$ or
CrilV) reagents. ${ }^{+}$1,4-DIIPs $\mathbf{1 f}$ and $\mathbf{1 h}$ bearing a benzyl group or an isopropyl group at the 4-position underwent simultancous dealkylation to give 3 as a sole product. This dealkylation probably may proceed via a radical cation intermediate 4 that is formed by single electron transfer (SET) from 1,4-D] IP to ] [TIB, as suggested in Seheme 2. .10 $^{-10}$ When 4-alkyl group is benzyl or isopropyl group. the 4-alkyl group rather than proton is expelled from 4 as a stable carbocation, resulting in the formation of dealkylated radical 5. Further oxidation of $\mathbf{5}$ ultimately gives the observed product 3.<smiles>[R]C1C(C(=O)OCC)=C(C)NC(C)=C1C(=O)OCC</smiles>

$$
\underset{\mathrm{CH}_{2} \mathrm{Cl}_{2}, \mathrm{rt}, 1-3 \mathrm{~min}}{\stackrel{\mathrm{PhI}(\mathrm{OH}) \mathrm{OTs}}{\longrightarrow}}
$$<smiles>[R]c1c(C(=O)OCC)c(C)nc(C)c1C(=O)OCC</smiles>

2a-1<smiles>CCOC(=O)c1cc(C)nc(C)c1C(=O)OCC</smiles>

3
Scheme 1

Table 1. Aromatization of Hantzsch 1.4-Dihydropyridines with PhlOH(OTs)

\begin{tabular}{|c|c|c|c|c|c|c|}
\hline $\begin{array}{l}1.4- \\
1) \mid 1 P_{s}\end{array}$ & $\mathrm{R}$ & Time & Pyridines & $\begin{array}{l}\text { Yield } \\
\%\end{array}$ & $\operatorname{mp}\left({ }^{\circ} \mathrm{C}\right)$ & $\begin{array}{c}\text { [it. mp } \\
\text { ("C) }\end{array}$ \\
\hline $1 \mathbf{a}$ & $\mathrm{C}_{0} \mathrm{H}_{5}$ & $1 \mathrm{~min}$ & $2 a$ & 92 & $60-61$ & $61-62^{3 t t}$ \\
\hline 1b & $3-\mathrm{NO}_{2} \mathrm{C}_{6} \mathrm{H}_{4}$ & $1 \mathrm{~min}$ & $2 b$ & 91 & $61-62$ & $61-63^{3 e}$ \\
\hline 10 & $4-\mathrm{NO}_{2} \mathrm{C}_{6} \mathrm{H}_{4}$ & $1 \mathrm{~min}$ & $2 c$ & 93 & $114-115$ & $5114-116^{3 k}$ \\
\hline ld & $2-\mathrm{ClC}_{6} \mathrm{H}_{4}$ & $2 \min$ & 2d & 94 & $61-62$ & $62^{c}$ \\
\hline 1e & $4-\mathrm{MeOC}_{6} \mathrm{H}_{4}$ & $2 \min$ & $2 \mathrm{e}$ & 91 & $50-51$ & $50^{3 / k}$ \\
\hline If & $\mathrm{C}_{0} \mathrm{H}_{5} \mathrm{CH}_{2}$ & $3 \mathrm{~min}$ & 3 & 95 & $67-68$ & $70-71^{3 k}$ \\
\hline $1 \mathrm{~g}$ & $\mathrm{C}_{0} \mathrm{H}_{5} \mathrm{CH}=\mathrm{CH}$ & $1 \mathrm{~min}$ & $2 \mathrm{~g}$ & 93 & $159-160$ & $162-163^{3 k}$ \\
\hline Ih & $\mathrm{MeCH}=\mathrm{CH}$ & $1 \mathrm{~min}$ & $2 h$ & 93 & $159-160$ & $162-163^{3 k}$ \\
\hline $1 \mathrm{i}$ & $\mathrm{CH}_{3}$ & $2 \min$ & $2 \mathrm{i}$ & 92 & oil & oil $^{3 / s}$ \\
\hline $1 \mathbf{j}$ & $\mathrm{C}_{2} \mathrm{H}_{5}$ & $2 \min$ & $2 \mathrm{j}$ & 92 & oil & oil $^{3.2}$ \\
\hline $1 \mathrm{k}$ & $n-\mathrm{C}_{3} \mathrm{H}_{7}$ & $2 \min$ & $2 k$ & 95 & oil & oil $^{? s}$ \\
\hline 11 & $\left(\mathrm{CH}_{3}\right)_{2} \mathrm{CH}$ & $2 \min$ & 3 & 98 & $68-69$ & $70-71^{3 k}$ \\
\hline
\end{tabular}

"all products are known compounds and were characterized by their mps and N.MR spectra. "yield refers to the isolated pure product. "Beifstem $\Gamma$ : II $22,127$. 
<smiles>[R]C1C(C(=O)OCC)=C(C)NC(C)=C1C(=O)OCC</smiles><smiles></smiles>

${ }^{-} \mathrm{OTS}^{\circ} \mathrm{OH}$ 3<smiles>Oc1ccc(O)cc1</smiles>
( $\mathrm{R}=$ benzyl, isopropyl)

$-\mathrm{R}^{+}$

4

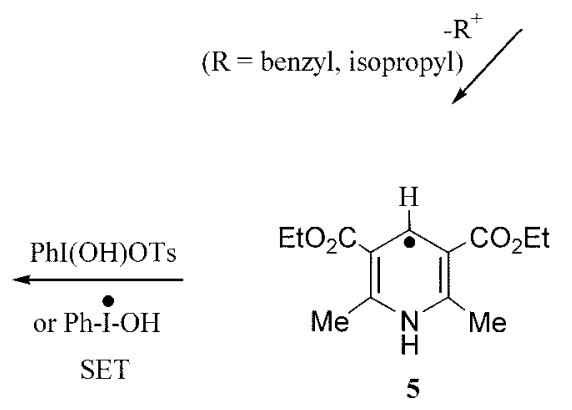

5<smiles>[Y]C1C(C(=O)OCC)=C(C)NC(C)=C1C(=O)OCC</smiles>

Scheme 2. Proposed mechanism of oxidation of 1,4-DIP's with Phl(OI) O'l's.

In summary, we have found that HTIB can serve as a mild. fast and efficient oxidant for the aromatization of Hantzsch 1.4-dilyydropy ridines to pyridines. ' In terms of reaction time. HTIB seems to be the most efficient oxidant for the 1.t-DHPs among known oxidants. to our best knowledge.

\section{References and Notes}

1. Triggle. D. J. In Comprehensine Hedicinal Chemistry: Emmell. J. C.. Volume Editor: I'ergamon: Oxiord. 1990: Vol. 3. Chapler 14.1 .

2. (a) Böcker, R. I1.; Gucngericl, F. P. J. Hed Chem. 1986. 29. 1596. (b) Guengericl, F. P.: Brian, W. R.: Iwasaki, M.: Sari. M.-A. Bämbielm, C.: Bentsson, P. J. Aked. Chem. 1991. 34. 1838 .

3. HNO 3: (a) Garcia. O.: Delgado. F.. Cano. A. C.: Alvarez. C. Tetrahedoff le't 1993. 34. 623. $\mathrm{CrO}_{3} \mathrm{AcOH}$ : (b) Sausins. A.: Duburs. G. Hereroctes 1988, 27, 291. PCC: (c) Vanden Frnde, I.-I:Mayenec. A.: Maquestiau. A Tetrohedrof 1992, 48, 46.3. PDC: (d) Ko, K.-Y.: Park, J.-Y. Buhl. Sonem Chem. Soc. 1995, 16, 200. $\mathrm{Cu}\left(\mathrm{NO}_{3}\right)_{2}:$ (e) Maquestiau. A.: Mayence. A.: Vanden Eynde. J.-I.

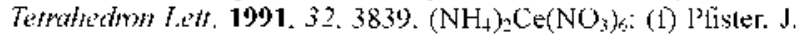
R. Simhesis 1990. 689. MnO : (a) Vanden Eynde. I.-J.: Delfosse. F.: Mavenee, A.: Van Iaverbeke. Y. Fetrohedron 1995, 51, 6511 KMnO.: (h) Vanden F.xnde. J.-J.: D'Otazio, R.; Van Havetbete, Y. Tetrahedron 1994, 50, 2479. NO: (i) Itoh, T.: Nagata, K.; Okada, M.: Ohsawa. A. Tetraftedon Lett. 1995. 36. 2269. Bi( $\left.\mathrm{NO}_{3}\right)_{3}$ ( (j) Mashraqui. S. H.: Karnik. M. A. Symthesis 1997. 713. RuCly Os: (k) Mashraqui. S. H.: Karnik. M. A. Tetrahtedon lett, 1998. 39. 4895. Mn $(O \wedge \mathrm{c})_{3}$ : (1) Varmo. R. S.: Kumar, D. Fetrafedron Lett. 1999, 40, 21. Photolysis: (m) Ji1, M.-7.: Yang, I... Wu, I..-M.;
Liu. Y.-C.: Liu. L.-L. (hem. Conmmen, 1998. 2451. In-MeOH: (n) Yadat. I. S.: Subba Reddy, B. V.: Sabitha. G.: Kiran Kumar Redd: G. S. Sumthesis 2000. 15.32

4. Ko. K.-Y.: Kim. I.-Y. Tetrahedrm Lett. 1999, 40, 3207.

5. (a) Moriarty. R. M.: Vaid. R. K.: Koser. (j. F. Simlett 1990. 365. (b) Koser. G. F. Ildrichimica.1cta 2001. 3f. 89.

6. Varvoglis. A. Tetrohedron 1997. 53. 1179.

7. Varma. R. S.: Kumar. D. J. Chem. Soc. Pertin Troms. I 1999. 1755 .

8. IITIB is available from $A$ ldrich Chemical Compans: Inc.

9. In a typical experiment. a solution of Hantzsch 1.4-DHP' (1a. 330 mg. $1.0 \mathrm{mmol}$ ) in dichloromethane $(5 \mathrm{~mL})$ was allowed to reac with l'hl(OH)OI's (470 mg. $1.2 \mathrm{mmol}$ ) and the mixlure was stirred at rt. The progress of the reaction was monitored by thin layer cluromatography (for 1 a. $R_{f}-0.20$; for 2 a, $R_{f}-0.36$ in hexanes: F.tOAc - 5: 1). After 1 mitn. the reaction was found to be complete. The reaction mixture was diluted with EtOAc $(20 \mathrm{~mL})$ and washed with aqueous $\mathrm{NaHCO}_{3}$ solution. The oreanic plase was separated. dried and concentrated under reduced pressure. Finally. the puritication by silica gel column chromatograply (hexanes:

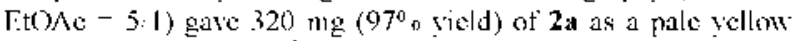
solid mp 60-61 C (I.t. ${ }^{2 \mathrm{a}} \operatorname{mp} 61-62$ C).

10. A mechenism involving single electron transfer (SET) steps has been proposed for the oxidation by o-iodosybenzoic acid (IBX). a hypervalent iodine(V) reagent. ${ }^{11}$ Dealkylation observed in the present stady suggests the involvement of similar SET process.

11. Nicolaon, K. C.: Montagnon, T.: Baran, P. S.: 7.hong. Y.-L. $J$. Am. Chem. Soc. 2002. I 1.2245.

12. Greater reactivity of PhI(OH)OT's compared to PhI(OAc) may be ascribed to the more ionic nature of $\mathrm{I}-\mathrm{O}$ T's bond in $\mathrm{PhI}(\mathrm{OH}) \mathrm{OT}$ 's. rendering the iodine atom more electrophilic. 